\title{
A Randomized Controlled Microbiological Trial on Efficacy of Photodynamic and Low-Level Laser Therapies As An Adjunct To Nonsurgical Treatment of Chronic Periodontitis
}

\author{
Suryakanth Malgikar ${ }^{1}$, Harinath Reddy S², Raja Babu P², Vidya Sagar S4
}

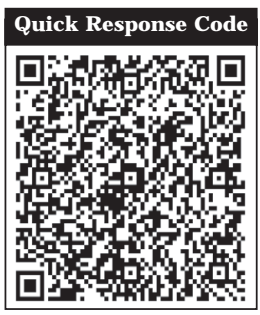

doi: $10.5866 / 2014.641674$

'Senior Lecturer

Department of Periodontics,

S. B. Patil Dental College and Hospital Bidar

${ }^{2}$ Professor

${ }^{3}$ Professor and Head

${ }^{4}$ Reader

Department of Periodontics,

Kamineni Institute of Dental Sciences, Nalgonda

\section{Article Info:}

Received: J uly 8, 2014

Review Completed: August 10, 2014

Accepted: November 9, 2014

Available Online: J anuary, 2015 (www.nacd.in)

(c) NAD, 2015 - All rights reserved

\section{Email for correspondence:}

drmalgikarsuryakanth@gmail.com

\begin{abstract}
:
Background: The oral cavity is colonized by a large number and highly diversified communities of micro-organisms. Bacterial biofilm on tooth or root surface is a major cause of gingivitis and periodontitis. A novel approach, photodynamic therapy (PDT), could be a solution to these problems. The advantage of this new approach includes rapid bacterial elimination, minimal chance of resistance development and safety of adjacent host tissue and normal micro flora. Recent preclinical and clinical data have suggested a potential benefit of photodynamic therapy (PDT) in thetreatment of periodontitis. Aim: The aim of this study was to evaluate the microbiological effects of adjunctive use of PDT \& combination of PDT with low-level laser therapy (LLLT) to non-surgical mechanical therapy (SRP) in the treatment of chronic periodontitis.
\end{abstract}

Methods: Twenty-four patients with untreated chronic periodontitis were randomly assigned in a split-mouth design into three treatment groups which included: Group I: SRP only, Group II: SRP \&PDT [1\% Methylene Blue solution], Group III: SRP, PDT \& LLLT. Microbiologic evaluation was done to assess the percentage of morphologically different microorganisms using dark field microscopic examination at baseline, 1, 3 and 6 months following therapy.

Results: All 3 therapies resulted in significant improvements from baseline in microbiological parameters. The improvement in microbiological parameters (cocci, bacilli \&spirochetes) was significantly greater in Group III compared to Group II and Group I.

Conclusion: The present study suggests that all the 3 treatment strategies seem to benefit the patients; an additional application of low-level laser therapy to single episode of PDT could be beneficial adjunct to nonsurgical treatment of chronic periodontitis in terms of percentage reduction of spirochetes compared to the other two groups. Direct subgingival delivery of methylene blue in different concentrations should be performed to further investigate the potential antimicrobial effect of soft lasers in human periodontal disease.

Key words: Periodontal diseases/microbiology; mechanical periodontal therapy; low-level laser therapy; photodynamic therapy; dark ground microscopy

\section{Indian Journal of Dental AdVAncements} Journal homepage: www. nacd. in 


\section{INTRODUCTION}

Periodontitis is the most prevalent disease in the oral cavity caused by Gram negative obligate anaer obes. The current treatment regimen involves mechanical debridement and this may be augmented with antibiotic therapy. ${ }^{1,2}$ The emergence of resistant microorganisms and a shift in the micro flora after extended use, limits the use of antimicrobials. ${ }^{3}$ Photodynamic therapy (PDT) could provide an al ternative for targeting microbes directly at thesite of infection, thus overcoming the problems associated with antimicrobials. Photodynamicaction describes a process in which light, after being absorbed by dyes, sensitizes organisms for visible light induced cell damage. Allison et al. described PDT as a therapy that "is truly the marriage of a drug and a light". ${ }^{4}$ Among laser applications, lowlevel laser therapy (LLLT) is recommended for its pain-reducing, wound healing promoter and antiinflammatory effects. ${ }^{5}$ In recent years, there has been a growing interest in usage of diode lasers for periodontal treatment dueto their antimicrobial and anti-inflammatory properties. ${ }^{6}$

Taken together, it is conceivable that photodynamic therapy in combination with low-level laser therapy might have biologically synergistic effects on control of microbial infections and the resultant inflammatory response as well as on promotion of tissue healing. Currently, to our knowledge till date there are no long term studies which combine photodynamic therapy and low-level laser therapy as an adjunctive 'package' in nonsurgical treatment of periodontitis. The present study was designed for comparative evaluation of changes in the percentage of morphologically different microorganisms using dark field microscopic examination following three treatment modalities; single episode of photodynamic therapy (PDT), a combined course of single episode of photodynamic therapy (PDT) with low-level laser therapy (LLLT) as an adjunct to non-surgical mechanical therapy in the treatment of chronic periodontitis.

\section{Materials and Methods}

The present single blind randomized, splitmouth controlled study was carried out at a single center, comparing the adjunctive use of single episode of PDT, combination of PDT with LLLT as an adjunct to nonsurgical mechanical therapy (SRP) in the treatment of chronic periodontitis. Evaluation was doneto assess the percentage of morphol ogically different microorganisms using dark field microscopic examination at baseline, 1, 3 and 6 months following therapy. The patients for this study were selected from outpatient's section, Department of Periodontology, Kamineni Institute of Dental Sciences, Narketpally, Nalgonda (Dist). Ethical committee of the institution approved the study.Twenty-four patients with untreated chronic periodontitis were enrolled in the study. Chronic periodontitis was diagnosed by macroscopic, radiography and probing pocket depth $\geq 5 \mathrm{~mm}$. The dentition of the patients displayed at least one site in each quadrant of the mouth having deep probing depth (PD) $\geq 5 \mathrm{~mm}$ and radiographic signs of alveolar bone loss.

\section{INCLUSION CRITERIA:}

1. Age - $18-60$ years

2. Periodontal pockets $\geq 5 \mathrm{~mm}$ of probing depth

3. No systemic contraindications

4. Vital and asymptomatic teeth

5. Patient should demonstrate acceptable oral hygiene maintenance

6. Healthy systemic condition

\section{EXCLUSION CRITERIA:}

1. Pregnant or lactating females

2. Use of immunosuppressive agents

3. Deleterious habits like smoking/alcohol consumption

4. Having taken systemic or local antibiotic therapy within preceding last 6 months

5. Active periodontal treatment within last 6 months

After baseline examination, a simple randomization approach ${ }^{7}$ using computer-generated random numbers was employed to assign patients in a split-mouth design to one of the following 3 treatment modalities:

Group I: Scaling and root planing only. 
Group II: Scaling and root planing \&single episode of photodynamic therapy using $1 \%$ methylene blue solution as photosensitizer.

Group III: Scaling and root planing, single episode of photodynamic therapy using $1 \%$ methylene blue solution \& low level laser therapy using a diode laser.

The probing pocket depth $\&$ clinical attachment level was measured using UNC-15 graduated periodontal probe. Measurements were done at selected sites. All measurements were performed by one experienced periodontal examiner, allowing an intra-experimental comparison of the values. Percentage agreement with another examiner within $1 \mathrm{~mm}$ was $>96 \%$. The reading was recorded to the nearest millimeter. $1 \%$ Methylene Blue was used as photosensitizer in the present study.

\section{Microbiological Assessment:}

Dark fiel d microscopic examination to assess the percentage of morphologically different microorganisms. ${ }^{8}$ Sub-gingival plaque sample, were taken from tooth with pocket of $\geq 5 \mathrm{~mm}$ with a sterile curette at baseline, 1, 3 and 6 months. Area specific gracey curettes were introduced through the pocket orifice as far apically as possible and sub-gingival plaque sample was removed. The sample was then suspended in eppendorf tube with $0.3 \mathrm{ml}$ of $0.9 \%$ sterile saline solution by vigorously agitating the tip of the instrument in the solution. In order to minimize clumping the samples were processed within 1 hour of collection. The microbial analysis was carried out in the Department of Oral and Maxillofacial Pathology, Kamineni Institute of Dental Sciences, Narketpally, Nalgonda (Dist).

\section{Darkfield Assessment of Microorganisms ${ }^{9}$}

One drop of the suspension was placed on a slide, cover slipped and examined by darkfield microscope with darkfield condenser at a magnification of X100. A manual counter for multiple cell types was utilized in making the classification. When the flow of fluid was sufficiently slow, it did not interfere with the random selection of microscopic fields and the classification of bacteria. If the flow was faster, a fixed reference line in the ocular was used to count the cells flowing past it. Clumps of cells in which all cells could not be clearly distinguished were not included in the counts. The first 100 organisms, from fiel ds selected at random, were counted and grouped into foll owing categories.

1) Coccoid cells: Cells approximately 0.5$1.0 \mu \mathrm{m}$ in diameter showing a bright outline with a dark center. In this category were also included cocco-bacillary forms the length of which was up to, but not more than, twice the width of the cell.

2) Rods: Non-flagellated cells with a bright outlineand a dark interior, approximately $0.5-1.5 \mu \mathrm{m}$ in width, with a width to length ratio between 1:2 and 1:6, and blunt or rounded cell ends. Branching cells were excluded.

3) Spirochetes: Hellicoidal cells, approximately0.2-0.5 $\mu \mathrm{m}$ in width and $10-20 \mu \mathrm{m}$ in length with both single- and double-contoured outlines and exhibiting varying degree of coiling.

\section{Periodontal and Adjunctive Laser Treatments}

On the first appointment, routine oral hygiene instructions were given. All patients received and one-stage full-mouth scaling \& root debridement empl oying both hand instruments (Hu-Friedy, USA) and a piezoelectric ultrasonic handpiece (EMS) under local anaesthesia of 2\% lidocaine with1:80000 adrenaline (Lignox 2\% A; Indoco Remedies Ltd, L32,Goa).

After periodontal debridement, the test teeth in Group III received additional low-level Iaser therapy using a Biostimulation probe provided by the manufacturer (DenLase; China Daheng Group, Inc. Beijing CHINA). The laser was fired at the orifice of the gingival margin at a distance of approximate $1-2 \mathrm{~mm}$, using a setting of $1.5 \mathrm{~W}$ as a continuous wave. Each tooth received 3 minutes of exposure. The patients returned after 2 days for the final low-level laser therapy on the same test teeth.

On second appointment i.e. after 24 hours the test teeth in Group II and Group III underwent a single episode of photodynamic therapy. The periodontal pockets werefilled with a $1 \%$ methylene blue solution as photosensitizer employing a blunt cannula starting from the bottom of the pocket to achieve both a complete filling of the pocket and coating of the root surface, which was left for $3 \mathrm{~min}$ before any excess was gently rinsed away. The remaining photosensitizer was activated for 30 seconds to 45 seconds per site. The diode laser 
(DenLase; China Daheng Group, Inc. Beijing CHINA) was operated at a peak power of $5.0 \mathrm{~W}$, with a pulse length of $200 \mu \mathrm{s}$ and pulse interval of $200 \mu$ s (average power $1.0 \mathrm{~W}$ ), using a $400 \mu \mathrm{m}$ fibreoptic tip and a wavelength of $980 \mathrm{~nm}$. The tip was initiated and introduced into the pocket with a smooth stroking action, starting coronally and working towards the bottom of the pocket.

\section{STATISTICAL ANALYSIS}

The data were analysed using the SPSS software 19.00 program (SPSS Inc., Chicago,IL, USA). The intra group comparison of changes in the subgingival microbiota like percentage of cocci, bacilli \&spirochetes scores were compared between Group I, Group II and Group III at various study intervals using one-way ANOVA test \& intergroup comparison was done by using Tukeys multiple post hoc test. Differences were considered as statistically significant at $\mathrm{p}<0.05^{*}$.

\section{RESULTS}

All 24 patients completed the 6 months study, with no patients reporting any postoperative pain, discomfort or complications at any of the follow-up appointments. The approach of patients appeared to be positive toward laser. Mean and standard deviation age in all the groups for males was 36.73 \pm 8.46 and for females was $34.33 \pm 6.80$.

The intra group comparison showed mean percentage of cocci scores for Group I at baseline was $33.88 \pm 4.45$ which increased to $45.13 \pm 4.94$ at 1 month, $54.58 \pm 4.75$ at 3 months \& $63.68 \pm 4.67$ at 6 months respectively. In Group II , mean percentage cocci scores at baseline was $34.47 \pm 3.16$ which increased to $47.00 \pm 6.57$ at 1 month, $58.08 \pm 4.89$ at 3 months \& $67.47 \pm 4.40$ at 6 months respectively. In Group III mean percentage cocci scoreat baseline was $34.28 \pm 2.76$ which increased to $51.63 \pm 5.23$ at 1 month, $63.30 \pm 4.28$ at 3 months $\& 72.55 \pm 4.25$ at 6 months respectively which are statistically significant $(P<0.0001 *)$. Significant increase in percentage of cocci scores were observed in all the groups at various intervals; however increase in cocci scores was highest viz. $-50.64 \%$ at 1 month $(p=0.001 *),-84.68 \%$ at 3 months $(p=0.001 *)$, and $111.68 \%$ at 6 months ( $p=0.001 *$ ) in Group III which were found to bestatistically significant $(p<0.001 *)$ (Table 1).
The inter group comparison revealed increase in percentage of cocci scores between Group I-II was statistically significant at 3 months $(p=0.04 *)$ and 6 months $\left(p=0.03^{*}\right)$. The increase in the percentage of cocci scores was statistically significant at all the study intervals between Group I-III $(p=0.001 *, p=0.001 *, p=0.001 *)$ and between Group II-III $\left(p=0.008^{*}, p=0.001 *, p=0.001 *\right)$ (Table 2).

The intra group comparison showed mean percentage of bacilli scores for Group I at baseline was $62.06 \pm 4.74$ which reduced to $52.30 \pm 6.14$ at 1 month, $44.62 \pm 4.39$ at 3 months and $35.41 \pm 4.62$ at 6 months respectively. In Group II , mean percentage of bacilli scores at baseline was $62.24 \pm 3.76$ which reduced to $51.88 \pm 6.79$ at 1 month, $40.93 \pm 5.33$ at 3 months and $32.32 \pm 4.41$ at 6 months respectively. In Group III mean percentage of bacilli score at basel ine was $62.71 \pm 2.63$ which reduced to $47.86 \pm$ 5.12 at 1 month, $36.48 \pm 4.25$ at 3 months and 27.43 \pm 4.25 at 6 months respectively. Significant reductions of bacilli scores were observed in all the groups at various intervals; however reduction in bacilli scores was highest viz. $23.69 \%$ at 1 month $(p=0.001 *), 41.83 \%$ at 3 months $(p=0.001 *)$ and $56.27 \%$ at 6 months $\left(p=0.001^{*}\right)$ in Group III which were found to be statistically significant $(p<0.001)$ (Table 3).

The inter group comparison revealed decrease in percentage of bacilli scores between Group I-II was statistically significant at 3 months $(p=0.04 *)$ and 6 months $\left(p=0.03^{*}\right)$. The decrease in the percentage of bacilli scores was statistically significant at all the study intervals between Group I-III ( $\left.p=0.001^{*}, p=0.001^{*}, p=0.001^{*}\right)$ and between Group II-III ( $p=0.008 *, p=0.001 *, p=0.001 *)$ (Table 4).

The intra group comparison showed mean percentage of spirochetes scores for Group I at baseline was $4.08 \pm 2.57$ which reduced to $1.71 \pm$ 1.25 at 1 month, $1.21 \pm 0.90$ at 3 months and $0.89 \pm$ 0.68 at 6 months respectively. In Group II, mean spirochetes score at baseline was $2.89 \pm 2.01$ which reduced to $1.10 \pm 1.03$ at 1 month, $0.57 \pm 0.73$ at 3 months and $0.23 \pm 0.39$ at 6 months respectively. In Group III mean spirochetes score at baseline was $3.06 \pm 2.04$ which reduced to $0.48 \pm 0.57$ at 1 month, $0.19 \pm 0.34$ at 3 months and $0.03 \pm 0.08$ at 6 months respectively. Significant reductions of spirochetes 
Table 1: Intra-group comparison of Group I, II and III with percentage of cocci scores at different time points by one-way ANOVA test

\begin{tabular}{|c|c|c|c|c|c|c|c|}
\hline \multirow[b]{2}{*}{ Groups } & \multirow[b]{2}{*}{ Baseline } & \multirow[b]{2}{*}{1 Month } & \multirow[b]{2}{*}{3 Months } & \multirow[b]{2}{*}{6 Months } & \multicolumn{3}{|c|}{$\begin{array}{l}\text { Percentage variation from Baseline } \\
\text { day to study interval time }\end{array}$} \\
\hline & & & & & $\begin{array}{l}\text { Baseline- } \\
\text { 1st Month }\end{array}$ & $\begin{array}{l}\text { Baseline - } \\
\text { 3rdMonth }\end{array}$ & $\begin{array}{l}\text { Baseline - } \\
\text { 6thMonth }\end{array}$ \\
\hline & Mean \pm SD & Mean \pm SD & Mean \pm SD & Mean \pm SD & Mean \pm SD & Mean \pm SD & Mean \pm SD \\
\hline Group I & $33.88 \pm 4.45$ & $45.13 \pm 4.94$ & $54.58 \pm 4.75$ & $63.68 \pm 4.67$ & $-11.25 \pm 3.26$ & $-20.70 \pm 3.70$ & $-29.80 \pm 4.95$ \\
\hline Group II & $34.47 \pm 3.16$ & $47.00 \pm 6.57$ & $58.08 \pm 4.89$ & $67.47 \pm 4.40$ & $-12.53 \pm 5.30$ & $-23.61 \pm 4.41$ & $-33.00 \pm 4.40$ \\
\hline Group III & $34.28 \pm 2.76$ & $51.63 \pm 5.23$ & $63.30 \pm 4.28$ & $72.55 \pm 4.25$ & $-17.36 \pm 4.87$ & $-29.03 \pm 4.13$ & $-38.28 \pm 3.53$ \\
\hline $\begin{array}{l}\text { \% of change } \\
\text { in Group I }\end{array}$ & - & - & - & - & $\begin{array}{l}-33.22 \% * \\
p=0.0000\end{array}$ & $\begin{array}{l}-61.11 \% * \\
p=0.0000\end{array}$ & $\begin{array}{l}-87.95 \% * \\
p=0.0000\end{array}$ \\
\hline $\begin{array}{l}\text { \% of change } \\
\text { in Group II }\end{array}$ & - & - & - & - & $\begin{array}{l}-36.35 \% * \\
p=0.0000\end{array}$ & $\begin{array}{l}-68.50 \% * \\
p=0.0000\end{array}$ & $\begin{array}{l}-95.73 \% * \\
p=0.0000\end{array}$ \\
\hline $\begin{array}{l}\text { \% of change } \\
\text { in Group III }\end{array}$ & - & - & - & - & $\begin{array}{l}-50.64 \% * \\
p=0.0000\end{array}$ & $\begin{array}{l}-84.68 \% * \\
p=0.0000\end{array}$ & $\begin{array}{c}-111.68 \% * \\
p=0.0000\end{array}$ \\
\hline F - VALUE & 0.1751 & 8.4945 & 21.3985 & 24.1485 & 11.9631 & 25.5721 & 23.5025 \\
\hline P-value & 0.8397 & $0.0005^{*}$ & $0.0000 *$ & $0.0000^{*}$ & $0.0000^{*}$ & $0.0000^{*}$ & $0.0000 *$ \\
\hline
\end{tabular}

*p $\varangle$.05- Statistically Significant

Table 2: Inter-group comparison of Group I, II and III with percentage of Cocci scores at different time points by Tukeys multiple post hoc test

\begin{tabular}{|c|c|c|c|c|c|c|c|c|}
\hline \multirow[b]{2}{*}{$\begin{array}{l}\text { Parameter } \\
(\mathbf{n}=\mathbf{2 4})\end{array}$} & \multirow[b]{2}{*}{ Groups } & \multirow[b]{2}{*}{ Baseline } & \multirow[b]{2}{*}{1 Month } & \multirow[b]{2}{*}{3 Months } & \multirow[b]{2}{*}{6 Months } & \multicolumn{3}{|c|}{$\begin{array}{c}\text { Percentage variation from Baseline } \\
\text { day to study interval time }\end{array}$} \\
\hline & & & & & & $\begin{array}{l}\text { Baseline- } \\
\text { VS } \\
\text { 1st Month }\end{array}$ & $\begin{array}{c}\text { Baseline - } \\
\text { VS } \\
\text { 3rdMonth }\end{array}$ & $\begin{array}{c}\text { Baseline - } \\
\text { VS } \\
\text { 6thMonth }\end{array}$ \\
\hline \multirow{3}{*}{$\mathrm{COCCl}$} & I vs. II & $P=0.8310$ & $P=0.4870$ & $P=0.0300^{*}$ & $P=0.0010^{*}$ & $P=0.5990$ & $P=0.0430 *$ & $P=0.0330^{*}$ \\
\hline & I vs. III & $P=0.9200$ & $P=0.0000^{*}$ & $P=0.0000^{*}$ & $P=0.0120 *$ & $P=0.0000^{*}$ & $P=0.0000^{*}$ & $P=0.0000^{*}$ \\
\hline & II vs. III & $P=0.9800$ & $P=0.0160^{*}$ & $P=0.0010^{*}$ & $\mathrm{P}=0.0120^{*}$ & $\mathrm{P}=0.0010^{*}$ & $P=0.0000 *$ & $P=0.0000^{*}$ \\
\hline
\end{tabular}

$* p \varangle 0.05$ - Statistically Significant

Table 3: I ntra-group comparison of Group I, II and III with percentage of Bacilli scores at different time points by one-way ANOVA test

\begin{tabular}{|c|c|c|c|c|c|c|c|}
\hline \multirow[b]{2}{*}{ Groups } & \multirow[b]{2}{*}{ Baseline } & \multirow[b]{2}{*}{1 Month } & \multirow[b]{2}{*}{3 Months } & \multirow[b]{2}{*}{6 Months } & \multicolumn{3}{|c|}{$\begin{array}{c}\text { Percentage variation from Baseline } \\
\text { day to study interval time }\end{array}$} \\
\hline & & & & & $\begin{array}{l}\text { Baseline- } \\
\text { lst Month }\end{array}$ & $\begin{array}{l}\text { Baseline - } \\
\text { 3rdMonth }\end{array}$ & $\begin{array}{l}\text { Baseline - } \\
\text { 6thMonth }\end{array}$ \\
\hline & Mean \pm SD & Mean \pm SD & Mean \pm SD & Mean \pm SD & Mean \pm SD & Mean \pm SD & Mean \pm SD \\
\hline Group I & $62.06 \pm 4.74$ & $52.30 \pm 6.14$ & $44.62 \pm 4.39$ & $35.41 \pm 4.62$ & $9.75 \pm 3.78$ & $17.44 \pm 3.93$ & $26.65 \pm 4.80$ \\
\hline Group II & $62.64 \pm 3.76$ & $51.88 \pm 6.79$ & $40.93 \pm 5.33$ & $32.32 \pm 4.41$ & $10.75 \pm 5.19$ & $21.70 \pm 4.53$ & $30.32 \pm 4.79$ \\
\hline Group III & $62.71+2.63$ & $47.86 \pm 5.12$ & $36.48 \pm 4.25$ & $27.43 \pm 4.25$ & $14.85 \pm 4.29$ & $26.23 \pm 3.83$ & $35.29 \pm 3.69$ \\
\hline $\begin{array}{l}\text { \% of change } \\
\text { in Group I }\end{array}$ & - & - & - & - & $\begin{array}{l}15.72 \% * \\
p=0.0000\end{array}$ & $\begin{array}{l}28.11 \% * \\
p=0.0000\end{array}$ & $\begin{array}{l}42.94 \% * \\
p=0.0000\end{array}$ \\
\hline $\begin{array}{l}\% \text { of change } \\
\text { in Group II }\end{array}$ & - & - & - & - & $\begin{array}{l}17.17 \% * \\
p=0.0000\end{array}$ & $\begin{array}{l}34.65 \% * \\
p=0.0000\end{array}$ & $\begin{array}{l}48.40 \% * \\
p=0.0000\end{array}$ \\
\hline $\begin{array}{l}\% \text { of change } \\
\text { in Group III }\end{array}$ & - & - & - & - & $\begin{array}{l}23.69 \% * \\
p=0.0000\end{array}$ & $\begin{array}{l}41.83 \% * \\
p=0.0000\end{array}$ & $\begin{array}{l}56.27 \% * \\
p=0.0000\end{array}$ \\
\hline F - VALUE & 0.2124 & 3.9430 & 18.1759 & 19.8474 & 8.8255 & 27.4729 & 22.7350 \\
\hline P-value & 0.8092 & 0.0239* & 0.0000* & 0.0000* & 0.0004* & 0.0000* & 0.0000* \\
\hline
\end{tabular}

$* \mathrm{p}<0.05$ - Statistically Significant 
Table 4: Inter-group comparison of Group I, II and III with percentage of Bacilli scores different time points by Tukeys multiple post hoc test

\begin{tabular}{|c|c|c|c|c|c|c|c|c|}
\hline \multirow[b]{2}{*}{$\begin{array}{l}\text { Parameter } \\
(n=24)\end{array}$} & \multirow[b]{2}{*}{ Groups } & \multirow[b]{2}{*}{ Baseline } & \multirow[b]{2}{*}{1 Month } & \multirow[b]{2}{*}{3 Months } & \multirow[b]{2}{*}{6 Months } & \multicolumn{3}{|c|}{$\begin{array}{l}\text { Percentage variation from Baseline } \\
\text { day to study interval time }\end{array}$} \\
\hline & & & & & & $\begin{array}{l}\text { Baseline- } \\
\text { VS } \\
\text { 1st Month }\end{array}$ & $\begin{array}{l}\text { Baseline - } \\
\text { VS } \\
\text { 3rdMonth }\end{array}$ & $\begin{array}{l}\text { Baseline - } \\
\text { VS } \\
\text { 6thMonth }\end{array}$ \\
\hline \multirow{3}{*}{ BACILLI } & I vs. II & $P=0.8580$ & $P=0.9690$ & $P=0.0220$ & $P=0.0040^{*}$ & $P=0.7180$ & $P=0.0020 *$ & $P=0.0160^{*}$ \\
\hline & I vs. III & $P=0.8230$ & $\mathrm{P}=0.0350^{*}$ & $P=0.0000^{*}$ & $P=0.0470 *$ & $P=0.0010^{*}$ & $P=0.0000^{*}$ & $P=0.0000^{*}$ \\
\hline & II vs. III & $P=0.9970$ & $P=0.0620$ & $P=0.0040^{*}$ & $\mathrm{P}=0.0470^{*}$ & $P=0.0060^{*}$ & $P=0.0010^{*}$ & $\mathrm{P}=0.0010^{*}$ \\
\hline
\end{tabular}

$* \mathrm{p}<0.05$ - Statistically Significant

Table 5: Intra-group comparison of Group I, II and III with percentage of Spirochetes scores at different time points by one-way ANOVA test

\begin{tabular}{|c|c|c|c|c|c|c|c|}
\hline \multirow[b]{2}{*}{ Groups } & \multirow[b]{2}{*}{ Baseline } & \multirow[b]{2}{*}{1 Month } & \multirow[b]{2}{*}{3 Months } & \multirow[b]{2}{*}{6 Months } & \multicolumn{3}{|c|}{$\begin{array}{c}\text { Percentage variation from Baseline } \\
\text { day to study interval time }\end{array}$} \\
\hline & & & & & $\begin{array}{l}\text { Baseline- } \\
\text { 1st Month }\end{array}$ & $\begin{array}{l}\text { Baseline - } \\
\text { 3rdMonth }\end{array}$ & $\begin{array}{l}\text { Baseline - } \\
\text { 6thMonth }\end{array}$ \\
\hline & Mean \pm SD & Mean \pm SD & Mean \pm SD & Mean \pm SD & Mean \pm SD & Mean \pm SD & Mean $\pm S D$ \\
\hline Group I & $4.08 \pm 2.57$ & $1.71 \pm 1.25$ & $1.21 \pm 0.90$ & $0.89 \pm 0.68$ & $2.37 \pm 1.54$ & $2.87 \pm 1.79$ & $3.19 \pm 1.98$ \\
\hline Group II & $2.89 \pm 2.01$ & $1.10 \pm 1.03$ & $0.57 \pm 0.73$ & $0.23 \pm 0.39$ & $1.79 \pm 1.16$ & $2.33 \pm 1.54$ & $2.66 \pm 1.82$ \\
\hline Group III & $3.06 \pm 2.04$ & $0.48 \pm 0.57$ & $0.19 \pm 0.34$ & $0.03 \pm 0.08$ & $2.58 \pm 1.71$ & $2.87 \pm 1.94$ & $3.03 \pm 2.03$ \\
\hline $\begin{array}{l}\% \text { of change } \\
\text { in Group I }\end{array}$ & - & - & - & - & $\begin{array}{l}58.12 \% * \\
p=0.0000\end{array}$ & $\begin{array}{l}70.38 \% * \\
p=0.0000\end{array}$ & $\begin{array}{l}78.14 \% * \\
p=0.0000\end{array}$ \\
\hline $\begin{array}{l}\% \text { of change } \\
\text { in Group II }\end{array}$ & - & - & - & - & $\begin{array}{l}61.82 \% * \\
p=0.0000\end{array}$ & $\begin{array}{l}80.40 \% * \\
p=0.0000\end{array}$ & $\begin{array}{l}92.07 \% * \\
p=0.0000\end{array}$ \\
\hline $\begin{array}{l}\% \text { of change } \\
\text { in Group III }\end{array}$ & - & - & - & - & $\begin{array}{l}84.20 \% * \\
p=0.0000\end{array}$ & $\begin{array}{l}93.73 \% * \\
p=0.0000\end{array}$ & $\begin{array}{l}99.18 \% * \\
p=0.0000\end{array}$ \\
\hline F - VALUE & 2.0098 & 9.1581 & 13.0160 & 24.0878 & 1.8110 & 0.7622 & 0.4608 \\
\hline P-value & 0.1418 & $0.0003^{*}$ & $0.0000^{*}$ & 0.0000* & 0.1712 & 0.4705 & 0.6327 \\
\hline
\end{tabular}

$* p<0.05$ - Statistically Significant

Table 6: Inter-group comparison of Group I, II and III with percentage of Spirochetes scores at different time points by Tukeys multiple post hoc test

\begin{tabular}{|c|c|c|c|c|c|c|c|c|}
\hline \multirow[b]{2}{*}{$\begin{array}{l}\text { Parameter } \\
(n=24)\end{array}$} & \multirow[b]{2}{*}{ Groups } & \multirow[b]{2}{*}{ Baseline } & \multirow[b]{2}{*}{1 Month } & \multirow[b]{2}{*}{3 Months } & \multirow[b]{2}{*}{6 Months } & \multicolumn{3}{|c|}{$\begin{array}{l}\text { Percentage variation from Baseline } \\
\text { day to study interval time }\end{array}$} \\
\hline & & & & & & $\begin{array}{l}\text { Baseline- } \\
\text { VS } \\
\text { 1st Month }\end{array}$ & $\begin{array}{l}\text { Baseline - } \\
\text { VS } \\
\text { 3rdMonth }\end{array}$ & $\begin{array}{c}\text { Baseline } \\
\text { VS } \\
\text { 6thMonth }\end{array}$ \\
\hline \multirow{3}{*}{$\mathrm{COCCl}$} & | vs. II & $P=0.1610$ & $P=0.0950$ & $P=0.0060 *$ & $P=0.1580$ & $P=0.3680$ & $P=0.5340$ & $P=0.6210$ \\
\hline & I vs. III & $P=0.2560$ & $P=0.0000^{*}$ & $P=0.0000^{*}$ & $P=0.0000^{*}$ & $P=0.8830$ & $P=1.0000$ & $P=0.9590$ \\
\hline & II vs. III & $P=0.9630$ & $P=0.0840$ & $P=0.1580$ & $P=0.0000^{*}$ & $P=0.1660$ & $P=0.5390$ & $P=0.7880$ \\
\hline
\end{tabular}

$* p<0.05$ - Statistically Significant 
scores were observed in all the groups at various intervals; however reduction in spirochete scores was highest viz. $84.20 \%$ at 1 month $\left(p=0.001^{*}\right)$, $93.73 \%$ at 3 months $(p=0.001 *)$ and $99.18 \%$ at 6 months $(p=0.001 *)$ in Group III which were found to be statistically significant (Table 5).

The inter group comparison revealed decrease in percentage of spirochetes scores at all the study intervals between Group I-II was not statistically significant $(p=0.3680, p=0.5340, p=0.6210)$, The decrease in the percentage of spirochetes scores was also statistically insignificant at all the study intervals between Group I-III ( $p=0.8830, p=1.000$, $\mathrm{p}=0.9590)$ and between Group II-III $(p=0.1160, p=0.5390, p=0.7880)$ (Table 6).

\section{DISCUSSION}

This study is a first of its kind to investigate the long-term microbiological effects of PDT and combined course of single episode of PDT with LLLT as an adjunct to non-surgical mechanical therapy in the treatment of chronic periodontitis. The results of this study show that statistically significant improvements of the parameters investigated were obtained in both treatment groups 6 months after completion of therapy. I ntergroup differences were not observed for percentage of spirochetes, although visibly larger reductions in percentage of bacilli and increase in cocci were seen in group III with adjunctive PDT and LLLT than in group I and group II.

Recently, photodynamic therapy has been used to treat localized microbial infections because the free radicals that are formed during photodynamic therapy might be toxic effect to the bacteria. Biostimulation has been reported in the literature with doses between 0.001 and $10 \mathrm{~J} / \mathrm{cm}^{2}$ as a therapeutic window. ${ }^{10}$ Low-level laser therapy also decreases the amount of inflammation and accelerates wound healing by changing the expression of genes responsible for the production of inflammatory cytokines in vivo. ${ }^{11}$

Even though the methodology of studies were not the same, Qadri et al found in their study that additional treatment with low-level lasers reduced periodontal gingival inflammation; theresults of our study are parallel to their study. ${ }^{12}$ Contrary to our findings, Lai et al suggested that low-power laser did not result in any additional clinical benefit. ${ }^{13}$ This might be a result of their application power density being low $\left(2.83 \mathrm{~mW} / \mathrm{cm}^{2}\right)$ and having limited application sites. The use of different kinds of lasers, doses, and duration preclude a comparison of these studies with our study.

\section{CONCLUSION}

The present study suggests that all the 3 treatment strategies seem to benefit the patients; an additional application of low-level laser therapy to single episode of PDT could be beneficial adjunct in terms of percentage reduction of spirochetes compared to the other two groups.

\section{REFERENCES}

1. Darby I. Non-surgical management of periodontal disease. Aust Dent J 2009; 54(1):86-95.

2. Heitz-Mayfield LJ A. Systemic antibiotics in periodontal therapy. Aust Dent J 2009; 54(1):96-101.

3. Feres M, Haffajee AD, Allard K, Som S, Goodson J M, Socransky SS. Antibiotic resistance of subgingival species during and after antibiotic therapy. J Clin Periodontal 2002; 29:724-735.

4. Allison RR, Baganto VS, Cuenca R, Downie GH, Sibata CH. The future of photodynamic therapy in oncology. Future Oncol 2006; 2:53-71.

5. Karlsson MR, Diogo Lofgren $\mathrm{Cl}$, J ansson $\mathrm{HM}$. The effect of laser therapy as an adjunct to non-surgical periodontal treatment in subjects with chronic periodontitis: A systematic review. J Periodontol 2008; 79:2021-2028.

6. Moritz A, Schoop U, Goharkhay $K$ et al. Treatment of periodontal pockets with a diode laser. Lasers Surg Med 1998; 22:302-301.

7. Altman DG, Bland J M. How to randomize. BMJ 1999; 319:703-704.

8. Greenwell H, Bissada NF. Variations in subgingival microflora from healthy and intervention sites using probing depth and bacteriologicidentification criteria.J Periodontol 1984; 55:391-397.

9. Listgarten MA, Hellden L. Relative distribution of bacteria at clinically healthy and periodontally diseased sites in humans. J ClinPeriodontol 1978; 5:115-132.

10. Wilson, M., Burns, T, Pratten, J . \& Pearson, G. J . Bacteria in supragingival plaque samples can be killed by low-power laser light in the presence of a photosensitizer. J App Bacteriol 1995; 78:569-774.

11. Tuner J , Hode L. Some basic laser physics. In: The Laser Therapy Handbook. Grangesberg, Sweden: Prima Books; 2007:317-338.

12. Qadri T, Miranda L, Tuner J, Gustafsson A. The short-term effects of low-level lasers as adjunct therapy in the treatment of periodontal inflammation. J ClinPeriodontol 2005; 32(7):714-719.

13. Lai SM, Zee KY, Lai MK, Corbet EF. Clinical and radiographic investigation of the adjunctive effects of a lowpower He-Nelaser in the treatment of moderate to advanced periodontal disease: A pilot study. Photomed Laser Surg 2009; 27:287-293. 